\title{
Aplikasi Mendeteksi Gerakan Tangan untuk Bermain Game Pingpong dengan Teknik Pengolahan Citra
}

\author{
Application to Detect Hand Movements to Play Ping Pong Game \\ with Image Processing Technique
}

\author{
I Komang Setia Buana \\ STMIK STIKOM Bali \\ E-mail: buana@stikom-bali.ac.id
}

\begin{abstract}
Abstrak
Keyboard, mouse, dan joystick merupakan perangkat keras yang sering digunakan untuk interaksi antara manusia dan komputer yang bersifat mekanis. Meskipun akurat, tetapi model interaksi yang dilakukan tidak bersifat alami sebagaimana manusia berinteraksi dengan sesamanya. Penggunaan peralatan-peralatan tersebut untuk mengoperasikannya membutuhkan adanya kontak langsung antara user dengan komputer. Dengan menggunakan visi komputer tidak membutuhkan kontak langsung pengguna dengan peralatan input, melainkan komputer menangkap gerakan pengguna melalui kamera video dan menginterpretasikannya. Gerakan yang diteliti disini adalah gerakan tangan. Kamera (webcam) merupakan alat yang digunakan untuk melakukan pengenalan tangan. Kamera ini digunakan sebagai sensor untuk mendeteksi pergerakan tangan. Pendeteksian gerakan tangan diimplementasikan dengan menggunakan library emguCV dan algoritma optical flow. Penerapan dari keakuratan aplikasi yang dibuat adalah dengan memainkan game pingpong. Uji coba menggunakan game pingpong sederhana dimana gerakannya kiri kanan atas bawah. Ketika kursor keatas otomatis bat pingpong keatas, dan seterusnya. Dari ujicoba penelitian dengan pencahayaan terang dimana resolusi webcame yang diuji coba 3 MP dan 1 MP, game pingpong lancar dimainkan sedangkan dengan pencahayaan redup, cursor lambat bergerak otomatis bat pingpong juga ikut lambat.
\end{abstract}

Kata Kunci - gerakan tangan, emguCV, pingpong, optical flow

\begin{abstract}
Keyboard, mouse, and joystick are hardware devices that are often used for the interaction between humans and computers being mechanical. Although accurate, but the model of interactions is not naturally as humans interact with each other. The use of such equipment to operate it requires direct contact between user and computer. By using a computer vision does not require direct contact with the user input device, but a motion capture computer user via a video camera and interpreting them. Movements studied here is the movement of the hand. The camera (webcam) is a tool used to perform the introduction of the hand. These cameras are used as sensors to detect hand movements. The detection of hand movements implemented using emguCV library and optical flow algorithm. Implementation of the accuracy of the application is made is by playing Ping-Pong game. Test using a simple ping pong game in which the movement left top right bottom. When the cursor upwards automatically ping pong bat up, and so on. From research trials with bright lighting where webcam tested resolution of 3 MP and 1 MP, a PingPong game played smoothly while the dim lighting, the slow-moving cursor automatically PingPong bat also slow.
\end{abstract}

Keywords — hand gestures, emguCV, ping pong, optical flow 


\section{PENDAHULUAN}

Seiring meningkatnya kemajuan teknologi komputer, peranan teknologi komputer juga semakin meningkat yang digunakan untuk kepentingan manusia. Salah satunya adalah bidang interaksi manusia dan komputer (IMK), atau sering disebut Human Computer Interaction (HCI). Keyboard, mouse, dan joystick merupakan salah satu perangkat keras yang sering digunakan untuk interaksi antara manusia dan komputer yang bersifat mekanis. Meskipun peralatanperalatan tersebut akurat dan handal (reliable), tetapi model interaksi yang dilakukan tidak bersifat alami sebagaimana manusia berinteraksi dengan sesamanya, penggunaan peralatan-peralatan tersebut untuk mengoperasikannya membutuhkan adanya kontak langsung antara user dengan komputer. Kebutuhan akan komunikasi yang lebih alami antara user dan komputer adalah tuntutan dari perkembangan teknologi komputer itu sendiri. Ketika user berinteraksi dengan komputer tidak hanya di depan meja, melainkan dalam lingkungan virtual (Virtual Reality), menggunakan komputer yang terpasang di badan (Wearable Computer), ataupun dengan perangkat Augmented Reality, maka perangkat-perangkat interaksi tradisional tidak lagi handal untuk digunakan.

Teknik interaksi berbasis visi komputer menjadi kandidat teknik interaksi yang bersifat alami. Teknik ini tidak membutuhkan kontak langsung pengguna dengan peralatan input, melainkan komputer menangkap gerakan pengguna melalui kamera video dan menginterpretasikannya. Input secara visual dapat memberikan kemampuan penginderaan pada komputer sebagaimana manusia melakukan penginderaan menggunakan mata. Interaksi antar manusia secara alami tidak membutuhkan mouse atau keyboard, melainkan diantaranya menggunakan tangan, mata, dan telinga untuk mendapatkan informasi dari lingkungan. Salah satu alternatif anggota badan manusia yang dapat dapat digerakan untuk menghasilkan beragam pose adalah tangan. Manusia secara alami terbiasa menggunakan tangan untuk melakukan komunikasi. Manusia menggerakkan tangan untuk mendapatkan beragam pose. Tiap pose memiliki maksud dan makna tersendiri sesuai dengan kesepakatan umum ataupun kesepakatan diantara personal yang melakukan komunikasi. Untuk dapat menangkap informasi yang diberikan, seseorang harus mampu melihat pose tangan dari lawan.

Pendeteksian menggunakan gerakan tangan telah diaplikasikan secara luas diantaranya pada bidang hiburan, pendidikan serta keamanan. Kamera (webcam) merupakan alat yang digunakan untuk melakukan pengenalan tangan. Kamera ini digunakan sebagai sensor untuk mendeteksi pergerakan tangan. Pendeteksian gerakan tangan diimplementasikan dengan menggunakan library emguCV dan salah satu metode yang banyak digunakan adalah optical flow [1]. Dalam metode ini, piksel dihitung berdasarkan pada posisi vektor dan itu dibandingkan dalam frame berikutnya, dengan asumsi kecerahan dari setiap titik objek konstan setiap waktu [2]. Setiap gerakan akan ditangkap oleh metode ini dengan cara mengingat sebuah gambar piksel diframe pertama, kemudian di frame kedua mencari piksel terdekat dengan kecerahan yang sama, sehingga diketahui objek-objek mana yang bergerak [3]. Penerapan dari keakuratan aplikasi yang dibuat adalah dengan memainkan game pingpong. Game pingpong merupakan game yang membutuhkan kecepatan gerakan untuk mendapatkan bola, sehingga diketahui keakuratan algoritma yang digunakan. 


\section{METODE PENELITIAN}

Perancangan sistem dalam penelitian ini dibagi menjadi dua kegiatan yaitu pengambilan data dan pengolahan data. Pengambilan data adalah hal yang dilakukan pertama kali, setelah itu data yang sudah diambil diolah menggunakan aplikasi.

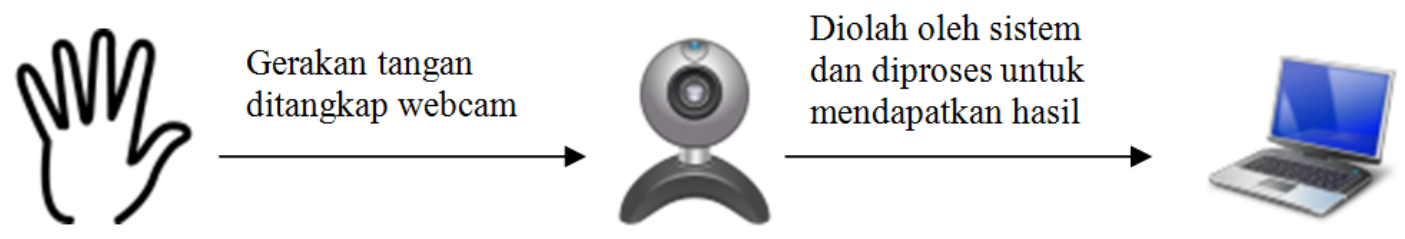

Gambar 1. Arsitektur Sistem

Gambar 1 Memperlihatkan arsitektur sistem, dimana gerakan tangan akan dibaca oleh aplikasi menggunakan webcame kemudian aplikasi akan mengolah data tangan tersebut dengan menggunakan teknik pengolahan citra dan metode optical flow sehingga gerakan tangan akan menggerakan cursor. Alur kerja sistem dijelaskan seperti gambar 2 berikut

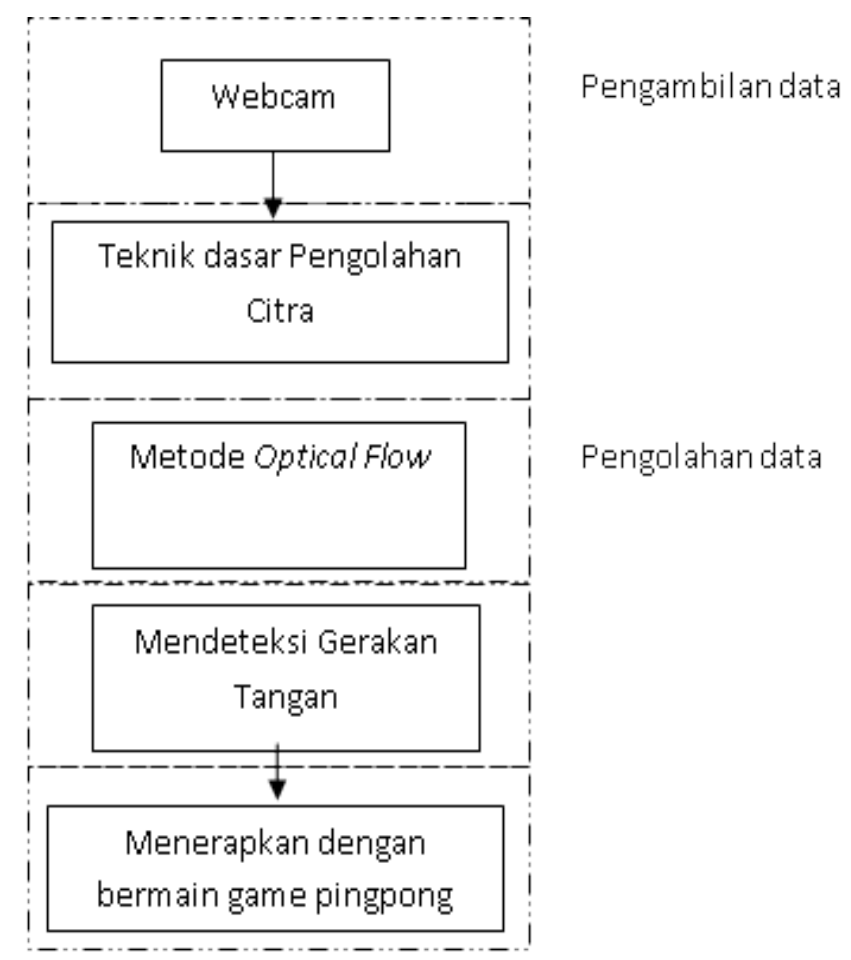

Gambar 2. Alur kerja sistem

\subsection{Pengambilan Data} berikutnya.

Data gerakan tangan diperoleh dari webcame. Data tersebut akan diolah untuk proses

\subsection{Pengolahan Data}

Dalam melakukan pengolahan data dalam penelitian ini menggunakan teknik pengolahan citra. Teknik pengolahan citra terdiri dari segmentasi, ektraksi fitur, dan proses morfologi pada citra. Setelah proses tersebut dilakukan, metode optical flow akan mendeteksi gerakan tangan. 
Tahap pengolahan data untuk bisa mendeteksi gerakan tangan:

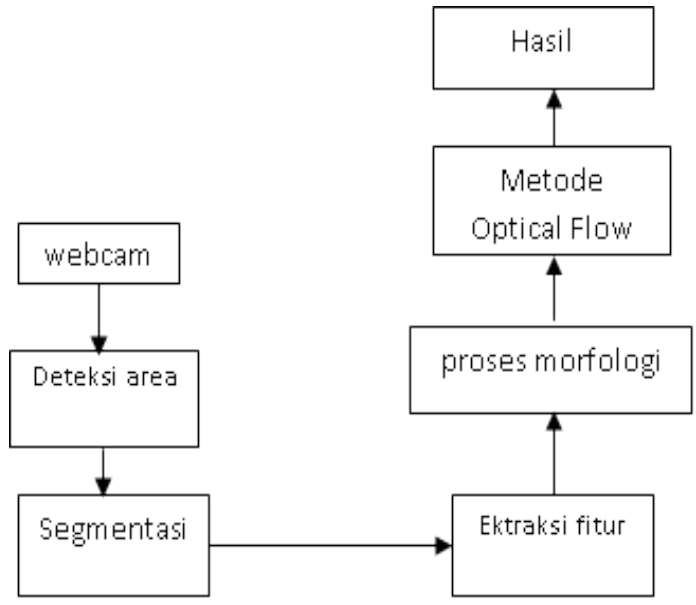

Gambar 3. Pengolahan data deteksi gerakan tangan

Tahap pengolahan merupakan tahap inti dari sistem yang akan dirancang. Tahap pengolahan dibagi menjadi beberapa proses.

\subsubsection{Tahap Deteksi Area}

Pada tahap ini, webcame akan mendeteksi area dari tangan yang akan dipakai sebagai bahan penelitian.

\subsubsection{Tahap Segmentasi}

Tahap ini yaitu melakukan pemisahkan objek dengan latar belakang(background). Proses pada tahap segmentasi adalah membaca frame pertama dan menganggap sebagai background frame, konversi background frame ke grayscale dan set nilai dari threshold. Proses tersebut dilakukan untuk frame pertama, dan untuk frame berikutnya yaitu frame ke dua dan seterusnya sampai frame terakhir yaitu pada tahap segmentasi, video yang sudah di konversi ke gambar (berupa frame), dibaca oleh sistem, kemudian konversi frame tersebut ke grayscale, setelah dikonversi, temukan perbedaan frame yang dibaca dengan frame sebelumnya. Setelah itu klasifikasi piksel apakah itu objek atau background, jika nilai objek lebih besar dari threshold maka piksel tersebut adalah objek dan simpan didalam objek vektor array baru, jika lebih kecil atau sama dengan nilai threshold maka nilai vector array adalah nol. Proses tersebut terus dilakukan sampai frame terakhir.

\subsubsection{Tahap Ekstraksi Fitur}

Tahap ini dilakukan untuk mendapatkan tepi dan sudut dari object di setiap frame. Tahap ektraksi fitur ini dengan membaca frame gambar, kemudian gambar tersebut harus sudah dirubah ke grayscale. Tahap dari ekstraksi dilakukan setelah tahap segmentasi. Setelah dipisahkan antara foreground dengan background maka dicari tingkat perubahan warna dari background dan forground sehingga didapat tepi dari forground [4]. Setelah tahap ekstraksi fitur selesai, lakukan proses morpologi, yaitu dilasi dan erosi, fungsi dari proses morfologi ini supaya memudahkan dalam melakukan placakan objek, setelah proses morfologi selesai, dilakukan proses cropping lokasi objek bisa dilakukan [5]. 


\subsubsection{Tahap Deteksi Objek}

Deteksi objek dilakukan dengan mengektraksi fitur setiap objek. Berdasarkan dimensi dari setiap objek ini memiliki fitur khusus. Metode diterapkan dalam penelitian ini adalah optical flow, yang digunakan untuk mendeteksi dan menunjukkan objek di setiap frame. Dalam metode ini, piksel dihitung berdasarkan pada posisi vektor dan itu dibandingkan dalam frame berikutnya untuk posisi piksel tersebut. Secara umum gerakan adalah sesuai dengan vektor posisi piksel [6].

Perhitungan dengan optical flow didasarkan pada dua asumsi:

1. Kecerahan dari setiap titik objek konstan setiap waktu.

2. Gerakan gambar di setiap frame berubah secara bertahap dari waktu ke waktu.

Misalkan kita memiliki sebuah gambar yang bergerak secara real time, $\mathrm{f}(\mathrm{x}, \mathrm{y}, \mathrm{t})$ merujuk kepada tingkat keabu-abuan (x, y) di waktu t.

1. Asumsi masing-masing piksel bergerak tetapi tidak merubah intensitas

2. Piksel di lokasi $(x, y)$ di frame1 adalah piksel pada $(x+\Delta x, y+\Delta y)$ di frame2.

3. Optical flow mengaitkan perpindahan vektor dengan setiap piksel [7].

Pelacakan objek mengacu pada proses menelusuri objek bergerak dalam setiap frame. Tugas pelacakan dilakukan oleh ekstraksi fitur objek dalam frame dan menemukan objek dalam urutan frame. Dengan menggunakan nilai-nilai lokasi objek di setiap frame dengan menggunakan metode optical flow, kita dapat menentukan posisi dari objek tersebut [8].

\section{HASIL DAN PEMBAHASAN}

Hasil dari penelitian ini adalah aplikasi yang dapat mendeteksi gerakan tangan yang digunakan untuk menggerakan cursor dan diujicoba dengan memainkan game pingpong.

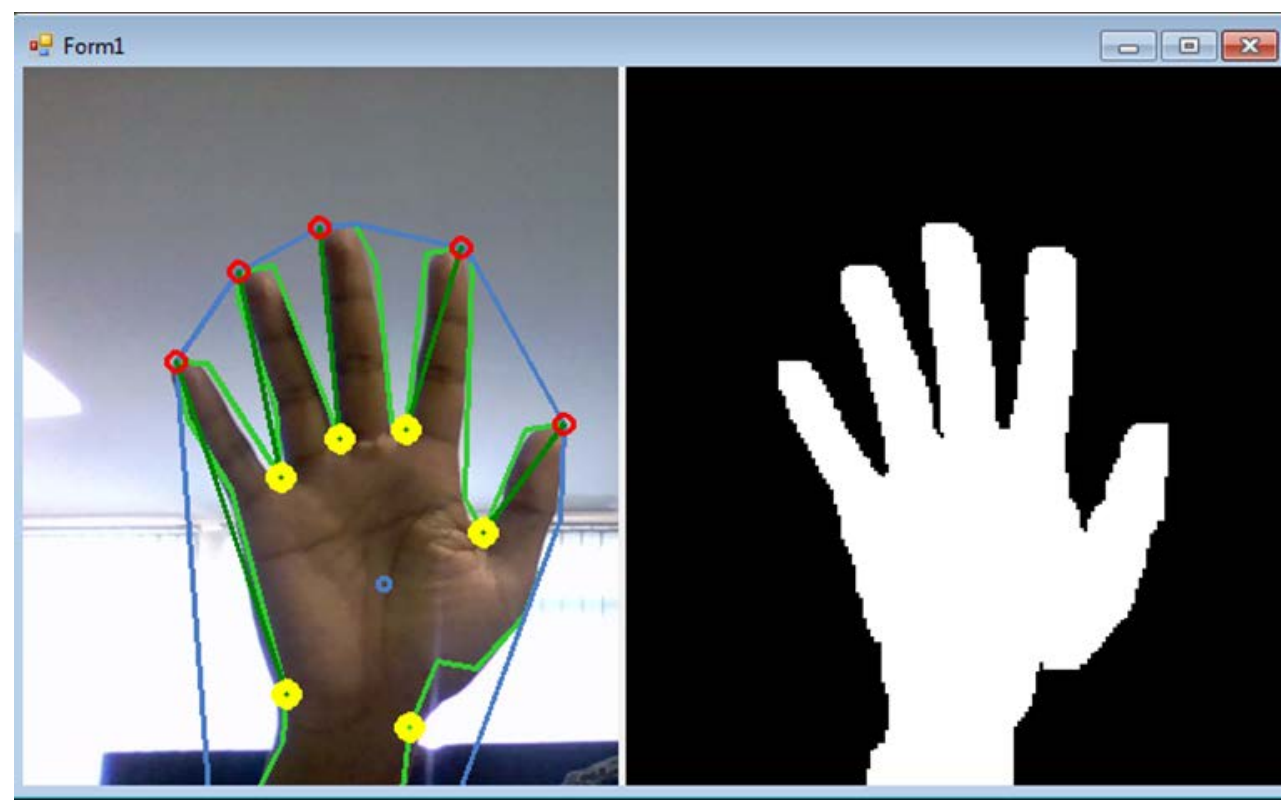

Gambar 4. Deteksi tangan dengan webcame resolusi 3 MP dan pencahayaan terang

Pada Gambar 4 merupakan hasil dari ujicoba menggunakan webcame dengan resolusi 3 MP dengan pencahayaan terang. Ketika jari terdeteksi lebih dari satu dan kurang dari enam maka cursor akan bergerak mengikuti gerakan tangan dan apabila tidak terdeteksi maka cursor akan diam. 


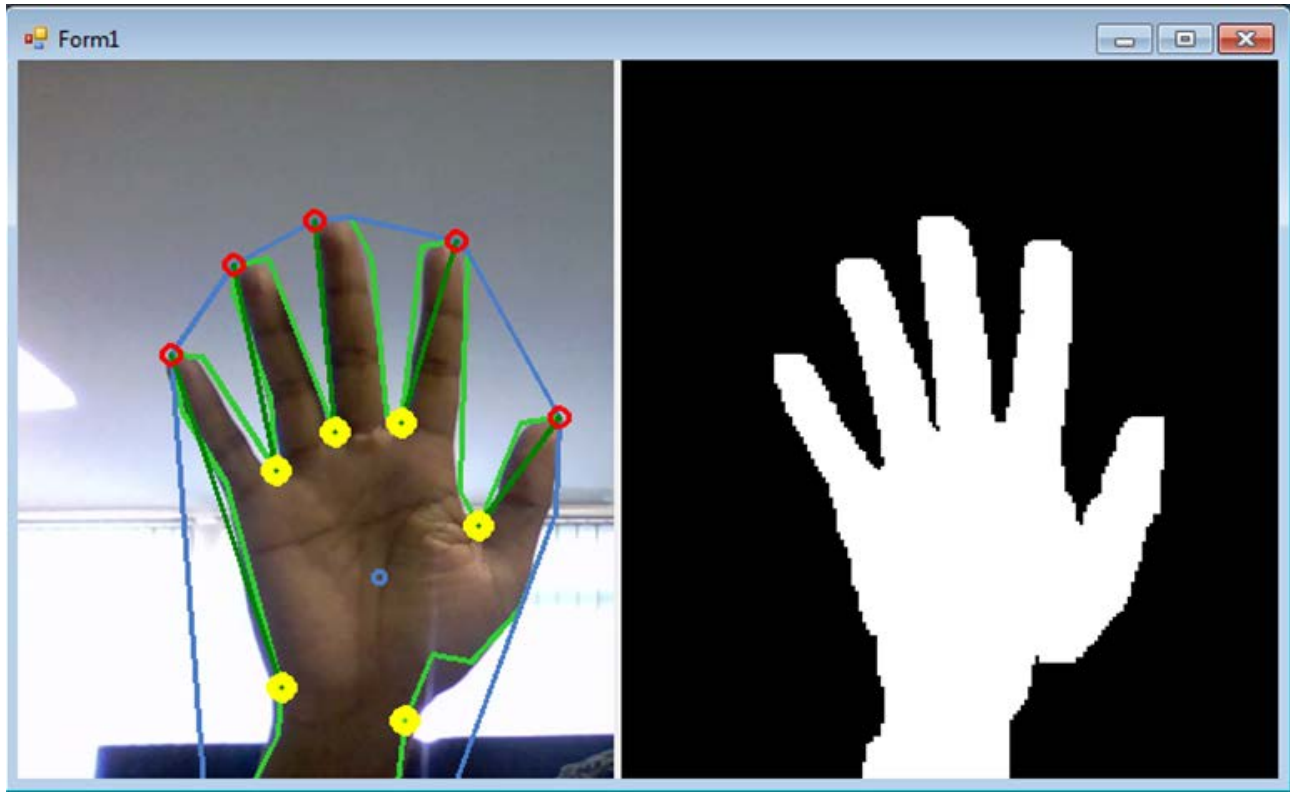

Gambar 5. Deteksi tangan dengan webcame resolusi 1 MP dan pencahayaan terang

Pada Gambar 5 merupakan hasil dari ujicoba menggunakan webcame dengan resolusi 1 MP dengan pencahayaan teramg. Ketika jari terdeteksi lebih dari satu dan kurang dari enam maka cursor akan bergerak mengikuti gerakan tangan dan apabila tidak terdeteksi maka cursor akan diam.

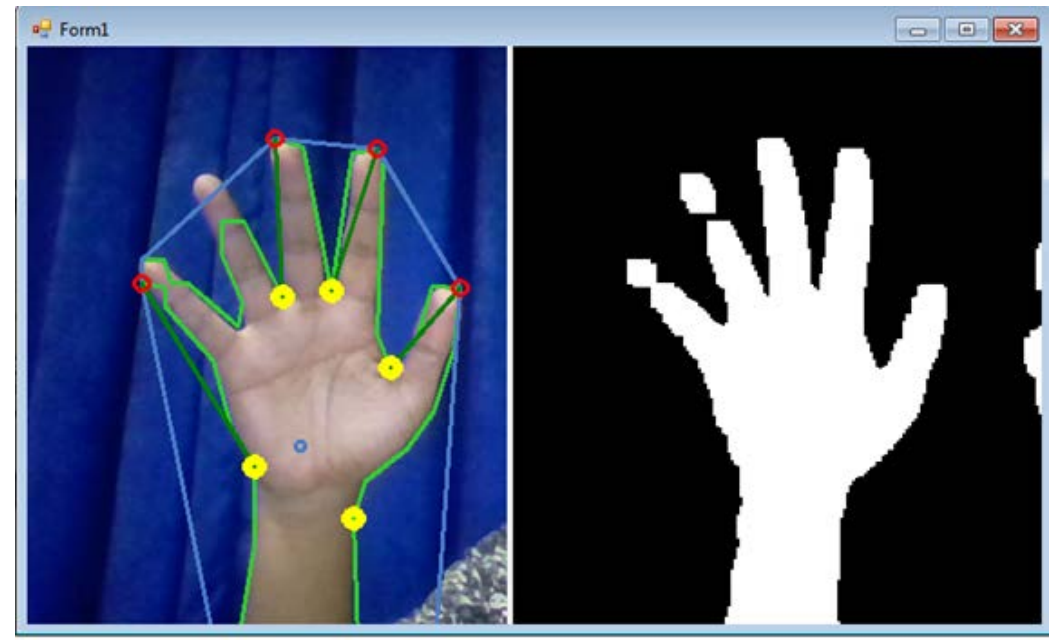

Gambar 6. Deteksi tangan dengan webcame resolusi 3 MP dan pencahayaan redup

Pada Gambar 6 merupakan hasil dari ujicoba menggunakan webcame dengan resolusi 3 MP dengan pencahayaan redup. Ketika jari terdeteksi lebih dari satu dan kurang dari enam maka cursor akan bergerak mengikuti gerakan tangan dan apabila tidak terdeteksi maka cursor akan diam. 
Citec Journal, Vol. 4, No. 1, November 2016 - Januari 2017

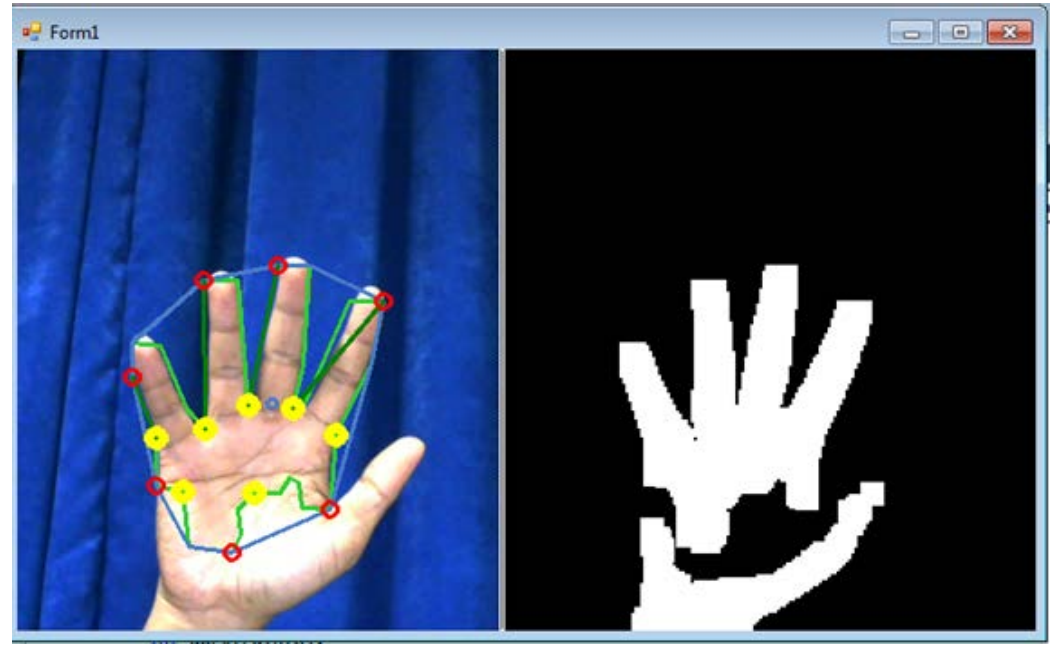

Gambar 7. Deteksi tangan dengan webcame resolusi 1 MP dan pencahayaan redup

Pada Gambar 7 merupakan hasil dari ujicoba menggunakan webcame dengan resolusi 1 MP dengan pencahayaan redup. Pendeteksian tangan kurang sempurna namun dapat menggerakan cursor karena jari masih terdeteksi ada empat karena di sistem sudah diatur bahwa jika terdeteksi jari lebih dari satu dan kurang dari enam maka cursor akan bergerak. Namun gerakan cursor sedikit lebih lambat.

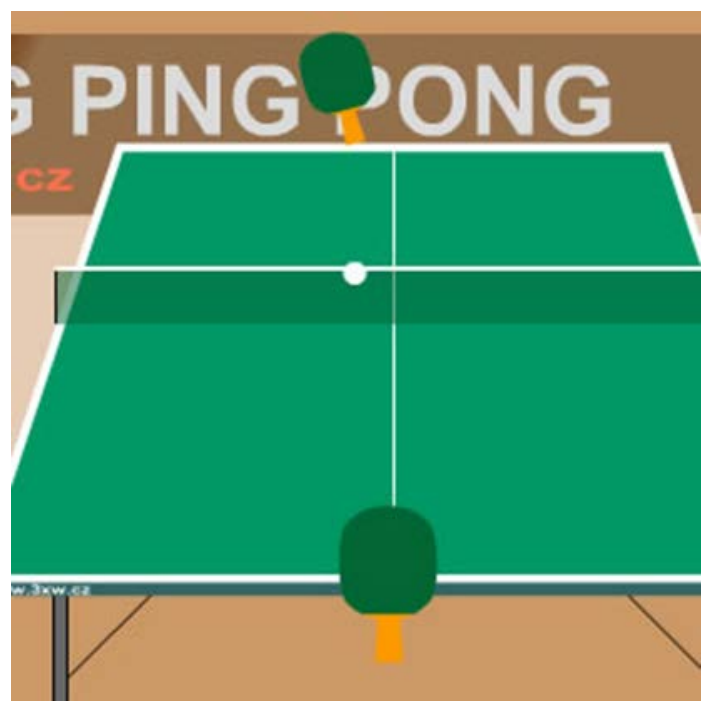

Gambar 8. Uji coba dengan game pingpong

Uji coba menggunakan game pingpong sederhana dengan gerakan kiri kanan atas bawah. Ketika kursor ke atas otomatis bat pingpong ke atas, dan seterusnya. Dari ujicoba penelitian dengan pencahayaan terang dimana resolusi webcame yang diuji coba 3 MP dan 1 MP, game pingpong lancar dimainkan sedangkan dengan pencahayaan redup, cursor lambat bergerak otomatis bat pingpong juga ikut lambat. 


\section{KESIMPULAN}

Kesimpulan yang dapat diambil dari penelitian ini adalah:

1. Aplikasi mendeteksi gerakan tangan untuk bermain game pingpong dengan teknik pengolahan citra dengan menggunakan metode optical flow berjalan lancar ketika pencahayaan terang dimana resolusi webcame yang diuji coba 3 MP dan 1 MP.

2. Jarak antara tangan dan webcame sangat berpengaruh untuk aplikasi ini, jika tangan terlalu dekat dengan webcame maka pendeteksian tidak akan berhasil bahkan membuat program jadi error.

\section{SARAN}

Saran yang dapat diberikan untuk penelitian ini adalah:

1. Menggunakan webcame dengan resolusi yang lebih tinggi.

2. Bisa dikembangkan dengan metode untuk menyempurnakan pendeteksian gerakan tangan pada saat pencahayaan redup.

\section{DAFTAR PUSTAKA}

[1] Umar, U., Soelistijorini, R., Haryadi, A. D., 2011, Tracking Arah Gerakan Telunjuk Jari Berbasis Webcam Menggunakan Metode Optical Flow. The 13th Industrial Electronics Seminar 2011 (IES 2011) Electronic Engineering Polytechnic Institute of Surabaya (EEPIS), Surabaya, 26 Oktober 2016.

[2] Revathi, R., Hemalatha, M., 2012, Certain Approach of Object Tracking using Optical Flow Techniques, International Journal of Computer Applications (0975 - 8887), Vol 53, No 8.

[3] Setia Buana, I Komang, 2014, Sistem Penghitungan Jumlah Kendaraan Dengan Teknik Pengolahan Citra Berbasis Java, Konferensi Nasional Sistem dan Informatika 2014, Denpasar, 7-8 November 2014

[4] Kadir, A., 2008, Dasar Pemrograman Java 2, Andi Offset, Yogyakarta.

[5] Kwong, K., Kavaler, R., Rajagopal, R., Varaiya, P., 2010, Real-Time Measurement of Link Vehicle Count and Travel Time in a Road Network, IEEE Transactions on Intelligent Transportation System, Vol 11, NO. 4.

[6] Huang, C. H., 2011, Video-based Traffic Analysis System Using a Hierarchical Feature Point Grouping Approach, First International Conference on Robot, Vision and Signal Processing (RVSP), TBD Kaohsiung City, 21-23 November 2011.

[7] Winarno, E., 2011, Aplikasi Deteksi Tepi pada Realtime Video menggunakan Algoritma Canny Detection. Jurnal Teknologi Informasi DINAMIK, Vol 16, No 1.

[8] Chen, Z., Cao, J., Tang, Y., Tang, L., 2011, Tracking of Moving Object Based on Optical Flow Detection, International Conference on Computer Science and Network Technology, 24-26 Desember 2011.

[9] Song, J. F., Bai, A N., Xue, R., 2011, A Reliable Counting Vehicles Method in Traffic Flow Monitoring, International Congress on Image and Signal Processing, 15-17 Oktober 2011. 